\title{
Introduction to the Special Issue: The Study of Religious and Spiritual Struggles: An Interdisciplinary Endeavor
}

\author{
Gina Magyar-Russell
}

check for updates

Citation: Magyar-Russell, Gina. 2021. Introduction to the Special Issue: The Study of Religious and Spiritual Struggles: An Interdisciplinary Endeavor. Religions 12: 53. https:// doi.org/10.3390/rel12010053

Received: 10 January 2021 Accepted: 12 January 2021 Published: 13 January 2021

Publisher's Note: MDPI stays neutral with regard to jurisdictional clai$\mathrm{ms}$ in published maps and institutional affiliations.

Copyright: () 2021 by the author. Licensee MDPI, Basel, Switzerland. This article is an open access article distributed under the terms and conditions of the Creative Commons Attribution (CC BY) license (https:// creativecommons.org/licenses/by/ $4.0 /)$.
Department of Psychology, Loyola University Maryland, Baltimore, MD 21210, USA; gmmagyarrussell@loyola.edu

Religious and spiritual ( $\mathrm{r} / \mathrm{s}$ ) struggles are relatively common human experiences and refer to pain, anger, fear, doubt, or confusion related to religious and spiritual beliefs, experiences, and practices (Exline 2013; Pargament et al. 2005). Broadly speaking, r/s struggles refer to distress or conflict in domains of life that individuals perceive as sacred. Because perceptions of the sacred are idiosyncratic and may vary greatly across cultures, worldviews, situations and from person to person, $r$ /s struggles may emerge in virtually any realm of life (Pargament 2007).

Given the vast nature of studying the sacred, the purpose of this special issue was to bring together the work of interdisciplinary scholars, researchers, and clinicians in a collection of papers that expands the current body of theoretical and empirical knowledge about $\mathrm{r}$ /s struggles. Over the past three decades, social scientists have developed various measures that have helped advance the study of $\mathrm{r} / \mathrm{s}$ struggles. One of the most recent and comprehensive of which, The Religious and Spiritual Struggles Scale (Exline et al. 2014) assesses r/s struggles in six domains: divine struggles, demonic struggles, doubt-related struggles, moral struggles, struggles of ultimate meaning, and interpersonal struggles. As crucial as consistent, reliable, and valid measurement is to the study of any phenomena, who is asking research questions and how they ask them is also of critical importance in understanding the manifestation, causes, and consequences of complex psychospiritual experiences like $\mathrm{r}$ / s struggles. Thus, the unique contributions of the 10 articles contained in this special issue includes the interdisciplinary lens applied to the study of $\mathrm{r} / \mathrm{s}$ struggles (psychology, social work, theology, chaplaincy, public health), the research methodologies employed (quantitative, qualitative, mixed methods), and the focus on understudied, underserved, and/or marginalized populations (clergy, sex-offenders, gay men, same-sex couples, veterans, atheists, and older adults).

In her contribution on spiritual struggles of 'nones' and 'spiritual but not religious' (SBNRs), Linda Mercadante interviewed one hundred nones who agreed to talk in-depth about their spiritual beliefs and practices. The qualitative interview was open-ended and semi-structured, covering existential issues such as ultimacy, human nature, community, and afterlife. Rooted in a theological framework, Mercadante's research uncovered four common themes in the spiritual struggles of nones, including transcendence/immanence, human nature, community, and afterlife. Her work adds support to the contention that all people, whether religious or not, have spiritual struggles, and in this sample r/s struggles centered around self-discovery and self-in-relation to others.

Three articles in the special issue address the adverse associations between $\mathrm{r} / \mathrm{s}$ struggles and mental health. In his review paper, Thomas Plante analyzes how clericalism contributes to religious, spiritual, and behavioral struggles among Catholic priests. Plante defines and describes clericalism and its role in contributing to adverse mental, emotional, interpersonal, and behavioral problems in priests with a focus on sexuality. He concludes the review by offering guidelines for working with Catholic seminarians and clerics, which include providing opportunities for straightforward conversations in which priests can feel understood and supported, as well as confronted about their behaviors within a health promoting and non-judgmental environment. 
In their article, Theresa Robinson, Gina Magyar-Russell, and Ralph Piedmont examine levels of religious struggle and their associations with symptoms of mental distress among men on the Maryland Sex Offense Registry. The authors review the societal marginalization experienced by individuals on sex offense registries and how experiences of religion and spirituality may include unique $\mathrm{r} / \mathrm{s}$ struggles for these individuals. The researchers found that greater levels of religious struggle were significantly related to higher scores on several indices of adverse mental health for these men. While acknowledging the harm and wrongdoing committed by these individuals, the authors outline compassionate approaches, that are linked to desistance from sexual offending, that can be taken toward working with sex offenders by religious communities, mental health practitioners, and within societal systems at large.

Utilizing a large internet-based sample, Ralph Piedmont, Jesse Fox, and Marion Toscano examine whether numinous constructs, including spiritual struggle, represent universal psychological qualities relevant to both theists and atheists. More specifically, their findings indicate that spiritual crisis is a unique predictor of emotional and characterological impairment in atheists, agnostics, and theists alike, offering support for the notion that both theists and atheists understand the numinous in similar ways, and may experience the adverse effects of spiritual struggle similarly as well.

Four articles speak to the potential for growth and resilience from $\mathrm{r} / \mathrm{s}$ struggle. In their article on $\mathrm{r} / \mathrm{s}$ struggles and spiritual resilience in marginalized older adults, Holly Nelson-Becker and Michael Thomas, working from a social work perspective, explore how older persons respond to life challenges and spiritual struggles through spiritually resilient responses. The authors performed two different community studies, one with 55 LGBQ older dyads in the U.S., UK, and Canada, and another with 75 older Black and Jewish persons residing in Chicago, IL. The authors identify themes and contexts in which the participants describe spiritual resilience and explore these themes within Nelson-Becker's (2013) framework of Resilience Properties in Ageing.

Working from a positive psychology framework, Allison Hart, Kenneth Pargament, Joshua Grubbs, Julie Exline, and Joshua Wilt contribute a quantitative study aimed at identifying predictors of self-reported growth following $\mathrm{r} / \mathrm{s}$ struggles. Specifically, this team of researchers makes a compelling argument for the role of wholeness in growth following $\mathrm{r} / \mathrm{s}$ struggle and carried out an empirical study of 1162 undergraduates from three U.S. universities. Their research begins to elucidate the conditions under which individuals may perceive growth from $\mathrm{r} / \mathrm{s}$ struggles.

In his article Renato Liboro carried out a community-engaged, qualitative study examining the combination of religious coping and family as supports for Catholic HIV-positive gay men dealing with religious struggles and other life challenges. His innovative work stems from a community psychology perspective and the identified themes demonstrate that although the participants experienced hardship and struggles directly linked to their Catholic upbringing, they strongly believe that their religion and family relationships provide them with tangible consolation and support. His work provides an in-depth analysis of the complex relationships between religious struggles, mental health, and well-being in a stigmatized and marginalized group of participants.

In their study conducted with 226 Polish adults, Beata Zarzycka, Anna Tychmanowicz and Dariusz Krok examine religious support and meaning making as mediators of the relationship between $\mathrm{r} / \mathrm{s}$ struggle and well-being. Their empirical work moves the study of $\mathrm{r} / \mathrm{s}$ struggles forward by illuminating mechanisms that explain growth and wellness following $\mathrm{r} / \mathrm{s}$ struggles as well as how religious support and meaning making interact differently with well-being depending on the type of $\mathrm{r} / \mathrm{s}$ struggle experienced.

Two articles in the special issue focus on the important issue of assessment of $\mathrm{r} / \mathrm{s}$ struggles. Joshua Wilt, Joyce Takahashi, Peter Jeong, Julie Exline, and Kenneth Pargament carry out an impressive mixed-methods study using open-ended and closed-ended measures of $\mathrm{r} / \mathrm{s}$ struggles. One of the take-aways from this work is that open-ended assessment may provide more contextualized $\mathrm{r} / \mathrm{s}$ struggles than those captured by standardized measures. 
Thus, the work in this paper furthers efforts in the field to accurately and proficiently assess $\mathrm{r} / \mathrm{s}$ struggles across diverse contexts and for different purposes, such as for research, in psychotherapy, and by clergy.

In their sample of military veterans Timothy Usset, Erika Gray, Brandon Griffiths, Joseph Currier, Marek Kopacz, John Wilhelm, and J. Irene Harris propose that psychospiritual development may be linked to symptoms of moral injury syndrome. Moral injury is a distinct type of spiritual struggle and "involves the emotional, behavioral, and spiritual sequalae of exposure to events that challenge cherished values and beliefs (Usset et al. 2020, p. 1)." These researchers suggest that assessment of the level of psychospiritual development may assist researchers and clinicians in identifying individuals more vulnerable to experiencing symptoms of moral injury syndrome after exposure to potentially morally injurious events. Importantly, this study also offers avenues for collaboration between social scientists, theologians, clergy, and health professionals by providing a psychospiritual lens with which to view risk factors for symptom presentation and severity of moral injury.

Although there is still much work to be done and different voices to learn from, the pioneering work in this special issue brings us closer to a richer understanding of the complex nature of $\mathrm{r} / \mathrm{s}$ struggles and how people are impacted and transformed by their encounters with the sacred.

Funding: This research received no external funding.

Data Availability Statement: Data sharing not applicable.

Acknowledgments: Thank you to the reviewers who gave selflessly of their time and provided quality reviews of the papers submitted to this special issue.

Conflicts of Interest: The author declares no conflict of interest.

\section{References}

Exline, Julie Juola, Joshua B. Grubbs, Kenneth I. Pargament, and Ann Marie Yali. 2014. The religious and spiritual struggles scale: Development and initial validation. Psychology of Religion and Spirituality 6: 208-22. [CrossRef]

Exline, Julie. 2013. Religious and spiritual struggles. In APA Handbooks in Psychology: APA Handbook of Psychology, Religion, and Spirituality: Vol. 1, Context, Theory, and Research. Edited by Kenneth I. Pargament, Julie J. Exline and James W. Jones. Washington: American Psychological Association, pp. 459-76.

Nelson-Becker, Holly B. 2013. Resilience in Aging: Moving through Challenge to Wisdom. In Handbook of Family Resilience. Edited by Dorothy S. Becvar. New York: Springer, pp. 339-57.

Pargament, Kenneth I., Nichole A. Murray-Swank, Gina M. Magyar, and Gene G. Ano. 2005. Spiritual struggle: A phenomenon of interest to psychology and religion. In Judeo-Christian Perspectives on Psychology: Human Nature, Motivation, and Change. Edited by William R. Miller and Harold D. Delaney. Washington: American Psychological Association, pp. 246-68.

Pargament, Kenneth. 2007. Spiritually Integrated Psychotherapy: Understanding and Addressing the Sacred. New York: Guilford Press.

Usset, Thomas J., Erika C. Gray, Brandon J. Griffin, Joseph M. Currier, Malek S. Kopacz, John S. Wilhelm, and J. Irene Harris. 2020. Psychospiritual developmental risk factors for moral injury. Religions 11: 484. [CrossRef] 